\title{
Influence of the abradant's composition on the selected physical properties in the process of front grinding of surfaces with microcrystalline sintered corundum grinding wheels
}

\author{
Czesław Niżankowski
}

Received: 20 November 2012 / Accepted: 29 April 2013 /Published online: 17 May 2013

(C) The Author(s) 2013. This article is published with open access at Springerlink.com

\begin{abstract}
This paper presents the results of experimental research on the influence of the composition of the abradants applied in the microcrystalline sintered corundum grinding wheels at the maximum temperature obtained in the grinding zone, maximum grinding power thrust component, grinding power feed component, active grinding power, and volumetric abradant wear. Tests were conducted in the conditions of front finishing grinding of flat surfaces of the objects made of corrosion-resistant steel, with austenitic structure. In our tests, we used a mini-grinder for flat surfaces, controlled by a CNC system, shank mounted grinding wheels made of mixed electrocorundum-cubitron abradant, a piezoelectric dynamometer, a thermal camera, a digital power analyzer, and a laser gauge. The test results were subjected to statistical and substantive analyses. It was found that, together with a proportional increase of the microcrystalline sintered corundum content in the grinding wheel's material, the values of the indicated physical properties displayed a decreasing tendency that could be determined by the trend functions, in the form of second-degree polynomials, without interaction. It was further found that such changes in the abradant composition significantly influenced the changes of the values of selected physical properties, and the test results well-approximated by the test object functions, in the form of third-degree polynomials, without interaction. The test object functions were characterized by the
\end{abstract}

C. Niżankowski $(\bowtie)$

Department of Mechanical Engineering, Institute of Production Engineering, Cracow University of Technology, Cracow, Poland e-mail: nizankowski@mech.pk.edu.pl occurrence of local extremes whose locations indicated that it was the most beneficial to operate grinding wheels with the abradant content belonging to the range of $7 \mathrm{CB}-9 \mathrm{CB}$, in the assumed testing conditions.

Keywords Grinding · Abradant composition · Temperature · Grinding power components · Grinding power · Grinding wheel's wear

\section{Introduction}

In 1910, Jeppson and Saunders developed a method of producing white noble electrocorundum by alumina melting in an electric-resistant arc furnace. They obtained a new abradant whose properties were considerably different from those of ordinary electrocorundum. White noble electrocorundum is primarily characterized by a higher chemical purity and a lower quantity of glassy phase in comparison to ordinary electrocorundum. Consequently, allotriomorphic grains of abradant grains have weaker bonds between each other, less glassy phase is concentrated on the grain edges, and the spaces between the grains are more open in each abradant grain [1]. Those properties allow for temperature reduction in the grinding zone and obtaining the so-called "cold grinding" effect. For that reason, white noble electrocorundum is mostly applied in the conditions of finishing machining. However, upon the material's development, it was found that the production process was unecological and required a lot of energy. In addition, the process made it impossible to produce grinding grains with required shape and dimensional proportions (Fig. 1) [2, 3]. 


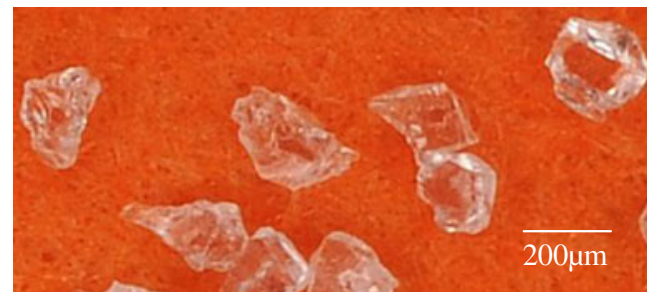

Fig. 1 A general view of abradant grains made of white noble electrocorundum 99A, grain number 60

Owing to that, research was implemented in the 1980 s to obtain a new generation sintered corundum, manufactured under the alumina submicropowder sintering technology applied to alumina precipitated from boehmite $(\gamma-\mathrm{AlOOH})$ by the sol-gel technology in a chemical process (Fig. 2) [4-8].

Microcrystalline sintered corundum (that is how it was called in international literature) was produced for the first time by the 3M Company in 1981 under the commercial name of CubitronTM. Presently, microcrystalline sintered corundum is manufactured by five companies based on slightly differing technologies. For that reason, particular material variations display different properties than those of CubitronTM and they are marked individually $[4,5]$.

The grains of microcrystalline sintered corundum (which is also sometimes called submicrocrystalline sintered corundum) are composed of strongly sintered particles, with the dimensions that are usually smaller than $1 \mu \mathrm{m}$ (Fig. 3) [4, 8, 9].

In comparison to noble electrocorundum, the abradant grains of microcrystalline sintered corundum are characterized by larger ductility and durability as a result of self-sharpening capability on the microscale, with slightly lower microhardness at the same time. Owing to those properties, grinding wheels made of microcrystalline sintered corundum have a very wide range of industrial applications, also in the area of dry grinding or grinding in the MQL conditions [9-12].

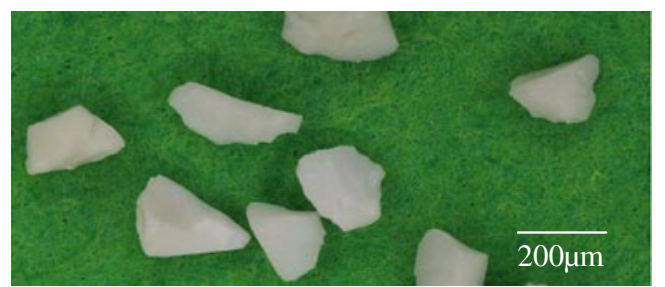

Fig. 2 A general view of abradant grains made of microcrystalline sintered corundum $\mathrm{CB}$, grain number 60

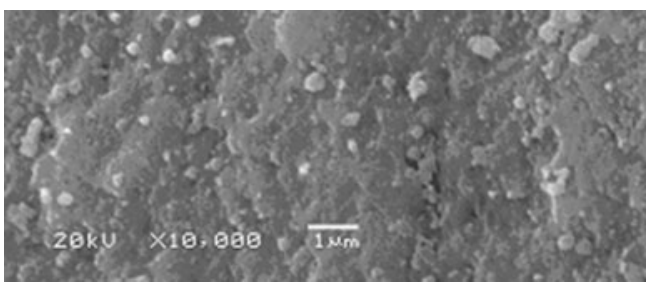

Fig. 3 Microstructure of abradant grains made of microcrystalline sintered corundum $\mathrm{CB}$

Presently, microcrystalline sintered corundum grinding wheels are usually made of mixed abradant containing white noble electrocorundum and microcrystalline sintered corundum, in various volumetric proportions. The proportions are reflected in the abradant marking system. For example, abradant $5 \mathrm{CB}$ means that $50 \%$ of the whole abradant volume is filled with microcrystalline sintered corundum (e.g., CubitronTM: for the needs of this study, we identify it by the $\mathrm{CB}$ abbreviation), while the remaining $50 \%$ is filled with white noble electrocorundum 99A. Such grinding wheels are usually fabricated with ceramic binder or, recently, a glass-crystalline one (Fig. 4). Currently, the market offers only a range of grinding wheels made of microcrystalline sintered corundum composed of oddnumbered products, e.g., $1 \mathrm{CB}, 3 \mathrm{CB}, 5 \mathrm{CB}, 7 \mathrm{CB}$, and 9CB. Grinding wheels with the abradant made of $100 \%$ microcrystalline sintered corundum are produced only for special applications $[4,9,10]$.

The catalogs of particular manufacturers mostly specify the general rule of the abradant's composition selection, which can be reduced to the principle that with higher hardness of the top surface of the workpiece (TSW), larger length of the machining path by a single grinding grain, and larger grinding depth, or higher relative grinding effectiveness to be obtained, we should increase the microcrystalline sintered corundum content in the grinding wheel's abradant volume [2,9]. That rule suggests linear or monotonic dependence between the abradant content and the physical parameters $[10$,

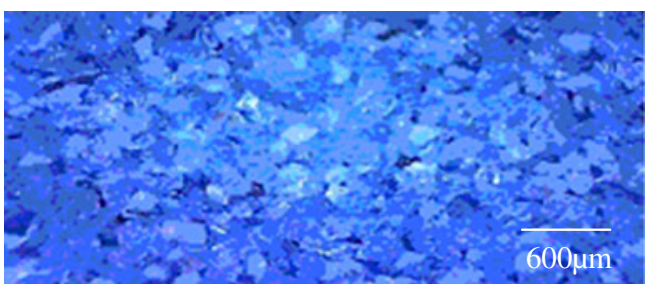

Fig. 4 The structure of a grinding wheel made of microcrystalline sintered corundum, abradant content $5 \mathrm{CB}$ 
13-15] selected for the purpose of this study. This suggestion is not, however, confirmed by the operating examples specified by manufacturers. Their examples clearly indicate that intermediate abradant composition applied in the grinding wheel production often prove to be optimum for the selected grinding conditions owing to the criteria that are customarily assumed for the evaluation of the grinding wheel's grindability or its physical parameters. The purpose of the present study was to find the answers to the questions: will the increase of the microcrystalline sintered corundum content in the abradant volume significantly influence the changes of the physical parameters considered in this study and are such changes linear in the process of front finishing grinding of the surfaces of materials made of stain-resistant steel, with austenitic structure?

\section{Description of experimental tests}

The design of experimental tests of the front finishing surface grinding process, using microcrystalline sintered corundum grinding wheels, with various abradant composition, is presented in Fig. 5.

Input parameter description:

$x_{1} \quad$ Percentage microcrystalline sintered corundum content in the grinding wheel's abradant (i.e., $1 \mathrm{CB}=10 \%, 3 \mathrm{CB}$ $=30 \%, 5 \mathrm{CB}=50 \%, 7 \mathrm{CB}=70 \%, 9 \mathrm{CB}=90 \%$ of microcrystalline sintered corundum in the abradant volume).

Output parameter description:

$z_{1} \quad$ Maximum temperature $\theta_{\max }$ in the grinding zone in Kelvin

$z_{2} \quad$ Thrust component $F_{\mathrm{p}}$ of the grinding power in newton

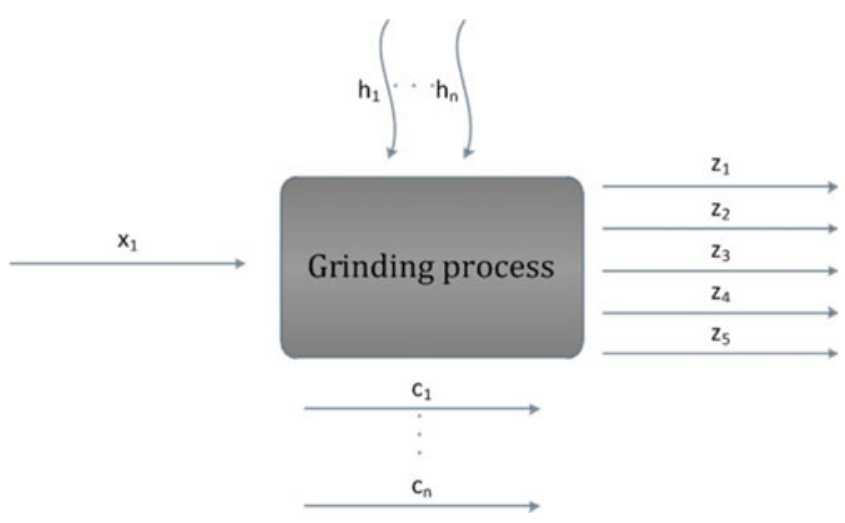

Fig. 5 Experimental test design

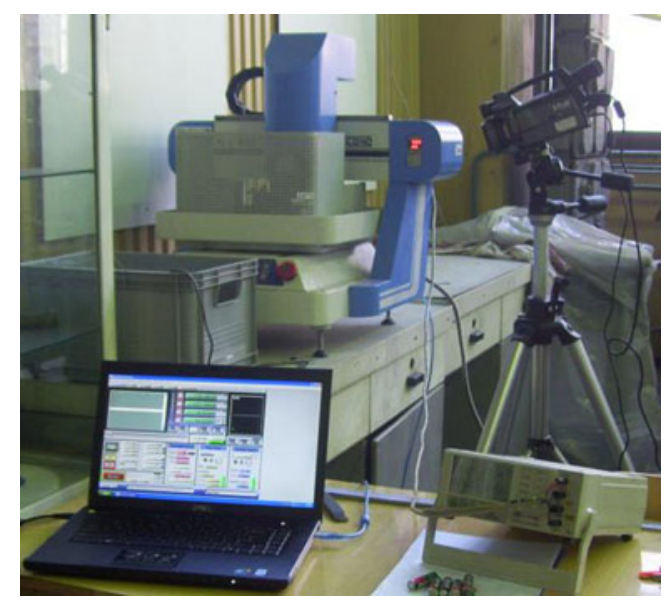

Fig. 6 A general view of the test bench (control unit + mini-grinder SIC330 CNC+digital power analyser DW6090+thermal camera FLIR SC620)

$z_{3} \quad$ Feed component $F_{\mathrm{f}}$ of the grinding power in newton

$z_{4} \quad$ Active grinding power $P_{\mathrm{c}}$ in watt

$z_{5}$ Volumetric wear of the grinding wheel $V_{\mathrm{m}}$ in cubic millimeter.

Constant factors:

$c_{1} \quad$ Mini-grinder SIC $330 \mathrm{CNC}$ (Knuth $\mathrm{GmbH}$; Fig. 6)

$c_{2} \quad$ Grinding wheel parameters: $521630 \times 30 \times 6$ XX60L7V (Andre Abrasives), where XX stands for changes according to $x_{1}$ (Fig. 5)

$c_{3}$ Grinding parameters:

- Grinding velocity $v_{\mathrm{c}}=28.3 \mathrm{~m} / \mathrm{s}$

- Depth of cut $a_{\mathrm{e}}=0.002 \mathrm{~mm}$

- Longitudinal feed velocity $v_{\mathrm{f}}=1 \mathrm{~m} / \mathrm{min}$.

$c_{4} \quad$ Grinding method: front finishing longitudinal surface grinding, with a rectangular table grinder

$c_{5} \quad$ Machining medium: dry grinding

$c_{6}$ Workpiece: cuboid samples, $100 \times 24 \times 20 \mathrm{~mm}$, with preliminary machining $(\mathrm{Ra}=2 \pm 0.1 \mu \mathrm{m})$, steel grade 1H18N9T (vel 1.4541 EN 10088), resistant to corrosion, with austenitic structure

$c_{7} \quad$ Grinding cycle: 3 -phase, without sparking out

$c_{8} \quad$ Truing method: diamond dresser M1020, with a 0.25 ct diamond, dressing depth $\mathrm{a}_{\mathrm{d}}=0.01 \mathrm{~mm}$ and the cover coefficient of $k_{\mathrm{d}}=3$

$c_{9} \quad$ Input parameter measurement methods

$c_{10}$ Number of machining passes: 60 leveling passes in a single grinding pass.

$c_{11}$ Time of one machining pass of the grinding wheel: $2 \mathrm{~s}$ 


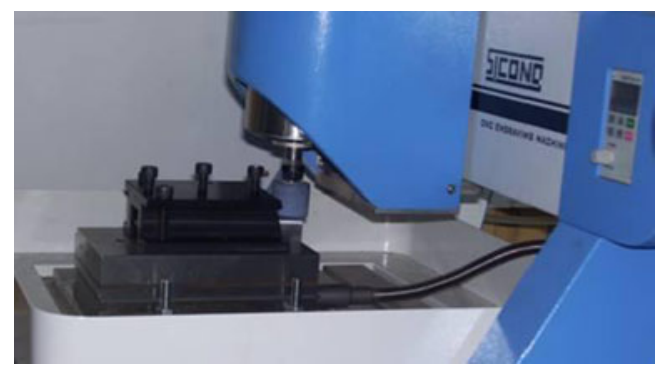

Fig. 7 The method of sample mounting in the KISTLER 9257B power meter and the form of the shank mounted grinding wheel placed in the grinder's spindle holder

Interfering factor description:

$h_{1}$ Dispersion of physical and mechanical properties of the grinding wheel

$h_{2}$ Dispersion of physical and mechanical properties of the workpiece

$h_{3} \quad$ Inaccuracy in the performance of the assumed grinding, dressing, and other parameters.

Experimental tests were conducted in accordance with a determined complete static plan, PS/DK, treating the front finishing grinding process as five separate elementary objects. The same grinding effectiveness was applied in all the test objects. The test results for each test object took into account five values measured in five grinding cycles (five replications).

The following dependences were the test object functions: $\theta_{\max }=f(\mathrm{XX}), F_{\mathrm{p}}=f(\mathrm{XX}), F_{\mathrm{f}}=f(\mathrm{XX}), P_{\mathrm{c}}=f(\mathrm{XX})$, and $V_{\mathrm{m}}=$ $f(\mathrm{XX})$, where $\mathrm{XX}$ was the changing abradant composition. First, the least square method was applied to determine the trend curves for each of the samples, taking into account the functions in the form of second-degree polynomial, without interaction. Next, approximation of test results was conducted by the computer equalization method, with the functions in the form of third-degree polynomials, without interaction, and the adequacy of those functions was checked at the significance level of $\alpha=0.05$. In case of both trend curves and approximating functions, the values of determination coefficients $R^{2}$ were

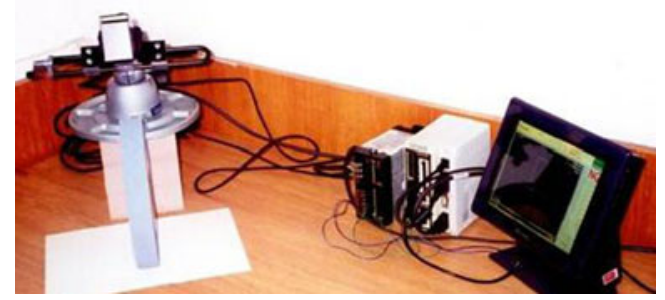

Fig. 8 Basic elements of the laser gauge

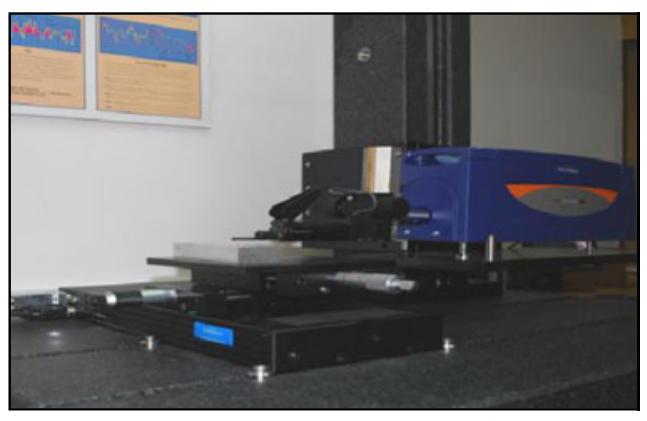

Fig. 9 Profilographometer Talysurf Form 50

calculated. The maximum temperature in the grinding zone was measured with the use of FLIR SC620 thermal camera, with the accuracy of $+/-(2 \% \mathrm{v} 2)$, operating in a set with a microcomputer equipped with ThermaCAM Researcher Pro 2.10 software. However, the measurements of active grinding power were made with the use of an NDN DW6090 digital power analyser (Fig. 6). The grinding force component measurements were made with the use of a KISTLER 9257B piezoelectric dynamometer (Fig. 7). The dynamometer was also connected to a PC, which recorded digital signals and carried out proper data processing. The measurements of the axial wear of the grinding wheel were taken with the use of a KEYENCE laser gauge (an LJ-G030 sensor and an LJG5001(P) controller), followed by conversion in respect of volumetric wear (Fig. 8). Regardless of the measurements specified in the input test parameter design, each time microscopic observation of the active grinding wheel surface (AGWS) was carried out and the topography of the top machined surface was checked using profilographometer TALYSURF FORM 50 from Taylor Hobson (Fig. 9). Those additional observations were carried out owing to the need of substantive evaluation of the causes of identified phenomena.

A selected thermal image of the grinding zone area, with a temperature record graph, is presented in Figs. 10 and 11. A selected printout from the power and grinding moment

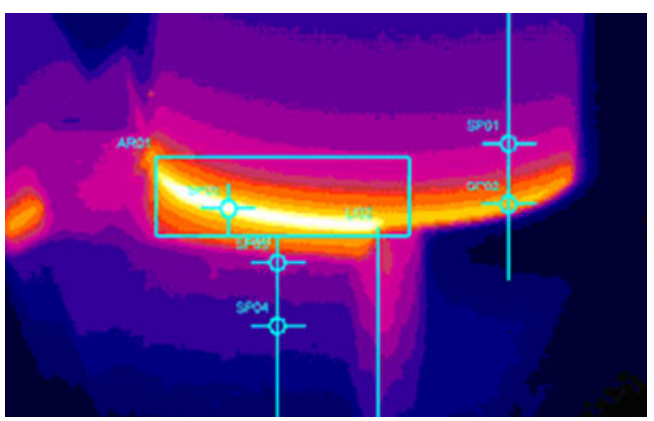

Fig. 10 IR image from the grinding zone, with marking of the measurement points and lines [16] 


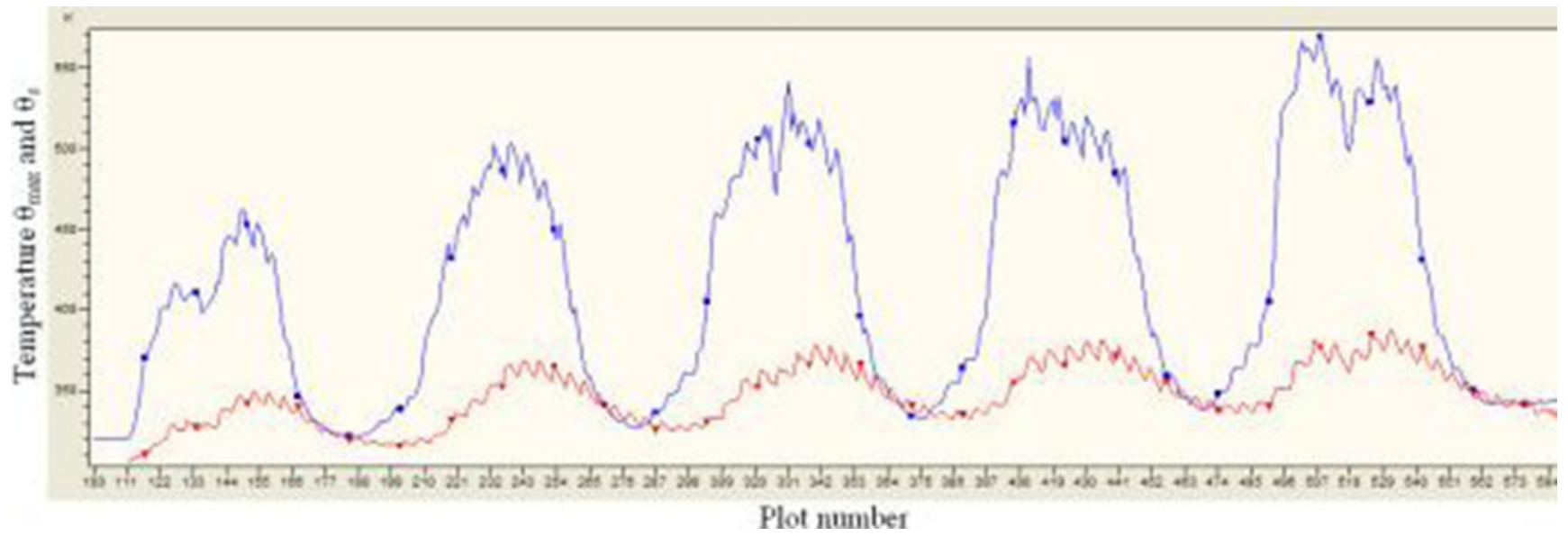

Fig. 11 Selected graph of the temperature record made during grinding with a $521630 \times 30 \times 6$ CB60L7V grinding wheel (blue line: $\theta_{\max }$, red line: $\theta_{\mathrm{s}}-$ maximum temperature in the grinding wheel)

component record, in connection with the KISTLER piezoelectric dynamometer, is presented in Fig. 12.

\section{Test results and statistical analysis}

The experimental test results relating to the influence of the abradant composition on the selected physical parameters in the process of front finishing grinding of flat surfaces of corrosion-resistant steel, using grinding wheels made of microcrystalline sintered corundum, with various abradant compositions, are presented in Table 1.

The results were subjected to statistical analysis. In the first stage, the analyst tried to establish whether the pro-

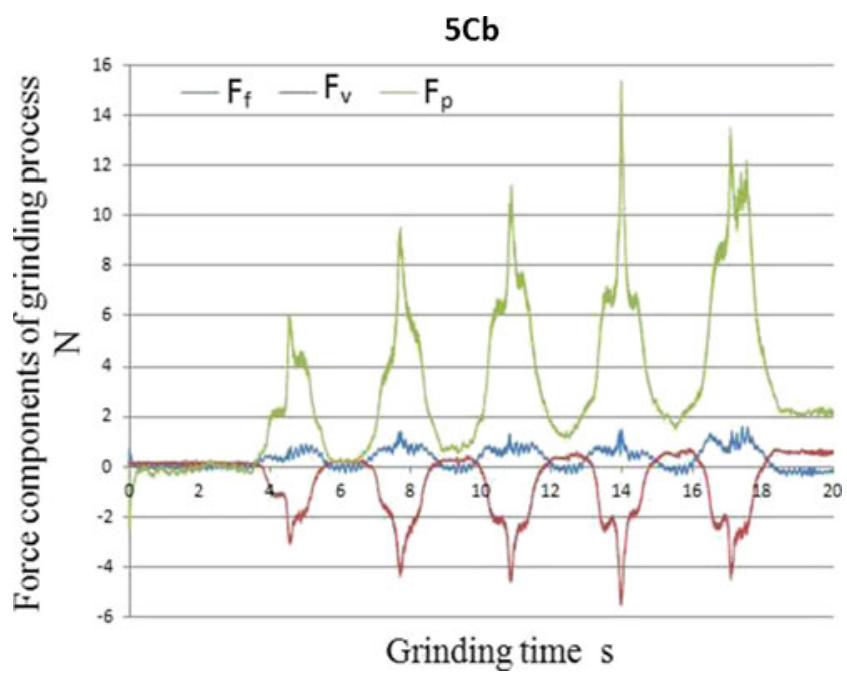

Fig. 12 Selected course of grinding force components; $521630 \times 30 \times$ 6 5CB60L7V grinding wheel portions of two variances (in the systems of " $\mathrm{u}$," $3 \mathrm{CB}$ to $1 \mathrm{CB}, 5 \mathrm{CB}$ to $1 \mathrm{CB}, 7 \mathrm{CB}$ to $1 \mathrm{CB}$, and $9 \mathrm{CB}$ to $1 \mathrm{CB}$ ) for the same input value of $z_{i}$ would be higher than one could expect when the samples had been collected from the same population.

Zero hypotheses were set as to variance equality. To check those hypotheses, the expressions of $\mathrm{S}^{2}\left(z_{i / \mathrm{u}}\right)$ were used as estimations of the variance of variables $z_{i / \mathrm{u}}$ (based on samples), with Fisher-Snedecor statistical distribution. The results of variance analysis by test $F$, on the example of variable $z_{1 / \mathrm{u}}$, is presented in Table 2 .

The comparison of the calculated values with the table values of $F$ does not allow to refute zero hypotheses, with variance equality at the significance level of $\alpha=0.05$. An analogous situation occurs in the cases of the remaining variables $z_{i}$. In the second stage of the statistical analysis of test results, the analyst checked whether there was a significant difference between the two average values $\bar{z}_{i}$ (from both test result groups, in each " $u$ " system), for the same input value $z_{i}$. Zero hypotheses were set as to equality of respective average values in particular "u" systems. Those hypotheses were verified by the Student's $t$ test, proper for checking the difference between the two average values. The results of the analysis with the test $t$ of the differences between the average values, on the example of variable $z_{1 / \mathrm{u}}$, are presented in Table 3.

The comparison of calculated values of $t$ with the table values of $t$ allows us to state that there are significant differences between the respective average values in the particular systems " $u$," and the zero hypotheses are not true at the significance level of $\alpha=0.05$. An analogous situation occurs in the case of the remaining variables $z_{i}$. In the third stage of the statistical analysis of 
Table 1 Physical parameter test results

\begin{tabular}{|c|c|c|c|c|c|c|c|c|c|c|}
\hline \multirow[t]{2}{*}{ Abradant composition } & \multicolumn{2}{|c|}{$\theta_{\max }(\mathrm{K})$} & \multicolumn{2}{|c|}{$F_{\mathrm{p}}(\mathrm{N})$} & \multicolumn{2}{|c|}{$F_{\mathrm{f}}(\mathrm{N})$} & \multicolumn{2}{|c|}{$P_{\mathrm{c}}(\mathrm{W})$} & \multicolumn{2}{|c|}{$V_{\mathrm{m}}\left(\mathrm{mm}^{3}\right)$} \\
\hline & $\bar{z}_{1}$ & $S_{1}$ & $\bar{z}_{2}$ & $S_{2}$ & $\bar{z}_{3}$ & $S_{3}$ & $\bar{z}_{4}$ & $S_{4}$ & $\bar{z}_{5}$ & $S_{5}$ \\
\hline $1 \mathrm{CB}$ & 646.83 & 57.02 & 27.6 & 8.4 & 7.5 & 3.41 & 405.8 & 2.04 & 0.236 & 0.009 \\
\hline $3 \mathrm{CB}$ & 810.80 & 33.14 & 35.4 & 9.69 & 10.0 & 4.69 & 502.0 & 1.90 & 0.233 & 0.011 \\
\hline $5 \mathrm{CB}$ & 526.55 & 39.31 & 11.2 & 3.28 & 1.6 & 0.29 & 266.4 & 4.22 & 0.157 & 0.008 \\
\hline $7 \mathrm{CB}$ & 468.79 & 41.75 & 13.5 & 3.49 & 0.4 & 0.17 & 248.8 & 4.92 & 0.079 & 0.002 \\
\hline $9 \mathrm{CB}$ & 549.51 & 70.20 & 12.14 & 3.11 & 1.5 & 0.54 & 263.6 & 3.72 & 0.079 & 0.003 \\
\hline
\end{tabular}

$\bar{z}_{i}$ is the arithmetic average of the measurement results of the $i$-th value. $S$ is the standard deviation of the measurement results of the $i$-th physical value

experimental test results related to the influence of the abradant content on the selected physical parameters, trend curves were designed, in the form of seconddegree polynomials, for particular test objects, with the calculation of the determination coefficients $R^{2}$, followed by test result approximations by the functions in the form of third-degree polynomials, without interaction, plus determination of their adequacy at the significance coefficient of $\alpha=0.05$. Since for each test object $\mathrm{F}_{\mathrm{TOF}} \leq$ $\mathrm{F}_{0.05 ; 2 ; 6}=5.14$, (where TOF $=$ Test Object Function), there are no grounds for refutation of the hypotheses that the determined TOF values are adequate (Figs. 13, 14, 15, 16, and 17). Standard deviations of the $i$-th physical values are included in Table 1.

\section{Merits-related tests results analysis}

Even a preliminary analysis of the obtained test object functions indicates the existence of local extremes. The increase of the values of the selected physical parameters during front finishing grinding of surfaces with microcrystalline sintered corundum grinding wheels of the $1 \mathrm{CB}-3 \mathrm{CB}$ range is noticeable, just as the parameter minimization when machining with the grinding wheels of the 7CB-9CB range.

The TSW analysis and AGWS microscopic observations indicated that the cause of the occurrence of the maximum

Table 2 Variance analysis by the test of $F$ experimental results, in comparative studies of maximum temperature in the grinding zone

\begin{tabular}{lccccccc}
\hline System u & $\frac{3 \mathrm{CB}}{1 \mathrm{CB}}$ & $\frac{5 \mathrm{CB}}{1 \mathrm{CB}}$ & $\frac{7 \mathrm{CB}}{1 \mathrm{CB}}$ & $\frac{9 \mathrm{CB}}{1 \mathrm{CB}}$ & & \multicolumn{2}{l}{ Table values of $F$} \\
\cline { 7 - 9 } & & & & & $F_{0,05 ; 4 ; 4}$ & $F_{0,1 ; 4 ; 4}$ \\
\hline $\begin{array}{l}\text { Calculated } \\
\text { values of } F\end{array}$ & 2.96 & 2.10 & 1.86 & 1.52 & 6.390 & 4.1072 \\
\hline
\end{tabular}

when grinding with a $3 \mathrm{CB}$ grinding wheel consisted in the appearance of the silting (gluing) process on the active grinding wheel's surface by the microchips which settled in the inter-blade spaces (Fig. 18). After those microchips were cut off from the active grinding wheel's surface, they were stuck to the workpiece's surface (Fig. 19), thus increasing the friction forces in the grinding process, and consequently causing increase of the selected physical values. The clogging of the active grinding wheel's surface results from the dominating grinding grain wear mechanism in case of 3CB abradant composition (Figs. 20 and 21). The increased friction between the grinding grains and the workpiece causes increase of the machining force value and of the grinding wheel's wear, as well as the increase of machining temperature and power (Figs. 13, 14, 15, 16, and 17). However, in case of $7 \mathrm{CB}$ abradant composition, the decrease of the physical values under analysis was caused by the intensification of the contribution of the grinding grain self-sharpening mechanisms to the process of grinding wheel's active surface wear (Figs. 22 and 23). The change of the dominating grain wear mechanism component resulted not only from the increase of the proportion of the Cubitron grinding grains with the self-sharpening capability in the abradant composition, but probably also from the changing minimum micromachining depth of single grinding grains, when micromachining after the traces of preceding grains (Figs. 20 and 22; Tables 4 and 5).

Table 3 Test $t$ analysis of differences between the average values of comparative experimental test results of the maximum temperature $\theta_{\max } \mathrm{W}$ in the grinding zone

\begin{tabular}{lcccccc}
\hline System u & $\frac{3 \mathrm{CB}}{1 \mathrm{CB}}$ & $\frac{5 \mathrm{CB}}{1 \mathrm{CB}}$ & $\frac{7 \mathrm{CB}}{1 \mathrm{CB}}$ & $\frac{9 \mathrm{CB}}{1 \mathrm{CB}}$ & & \multicolumn{2}{c}{ Table values of $t$} \\
& & & & $t_{0,05 ; 8}$ & $t_{0,1 ; 8}$ \\
\hline $\begin{array}{c}\text { Calculated } \\
\text { values of } t\end{array}$ & 8.59 & 7.02 & 10.66 & 5.63 & 2.306 & 1.860 \\
\hline
\end{tabular}




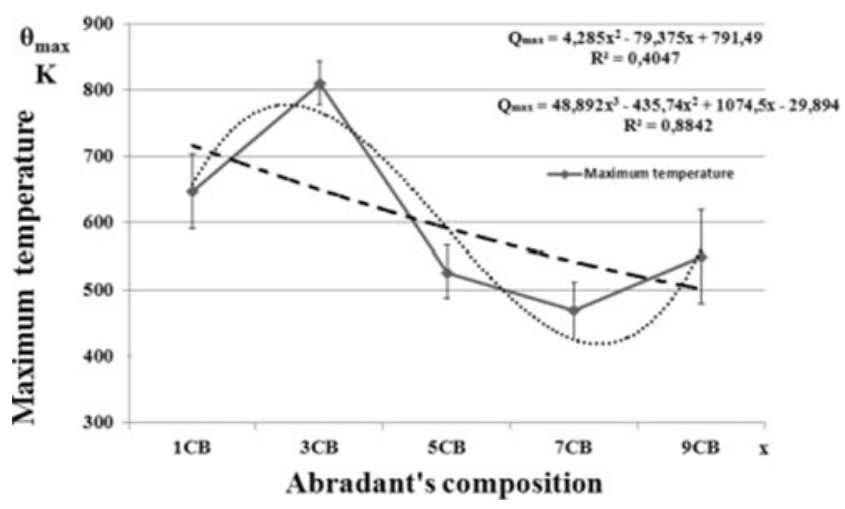

Fig. 13 The influence of microcrystalline sintered corundum abradant composition on the maximum temperature in the grinding zone

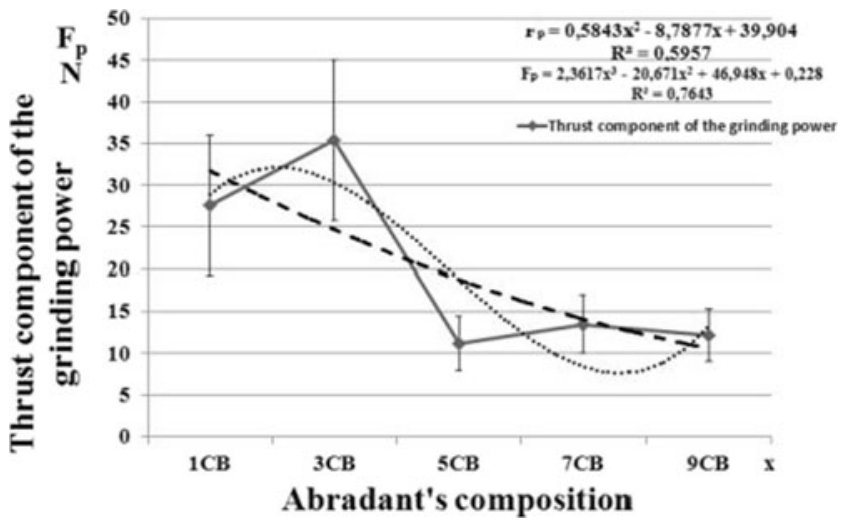

Fig. 14 The influence of microcrystalline sintered corundum abradant composition on the grinding power thrust component

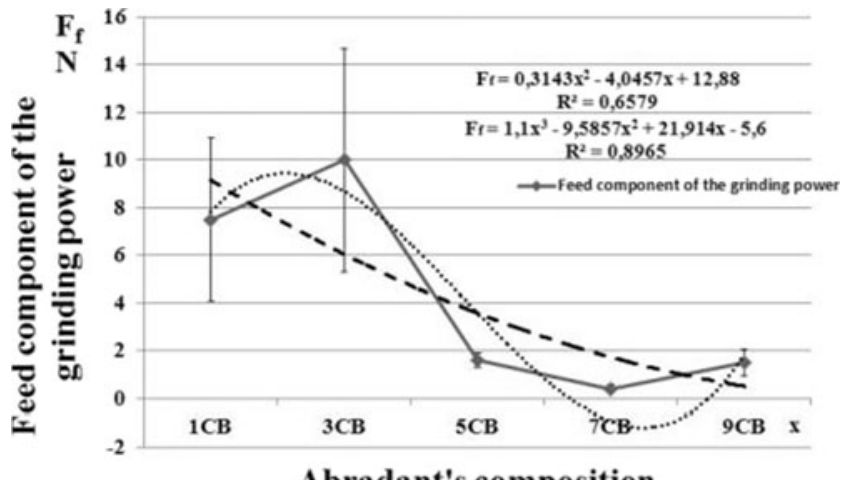

Abradant's composition

Fig. 15 The influence of microcrystalline sintered corundum abradant composition on the grinding power feed component

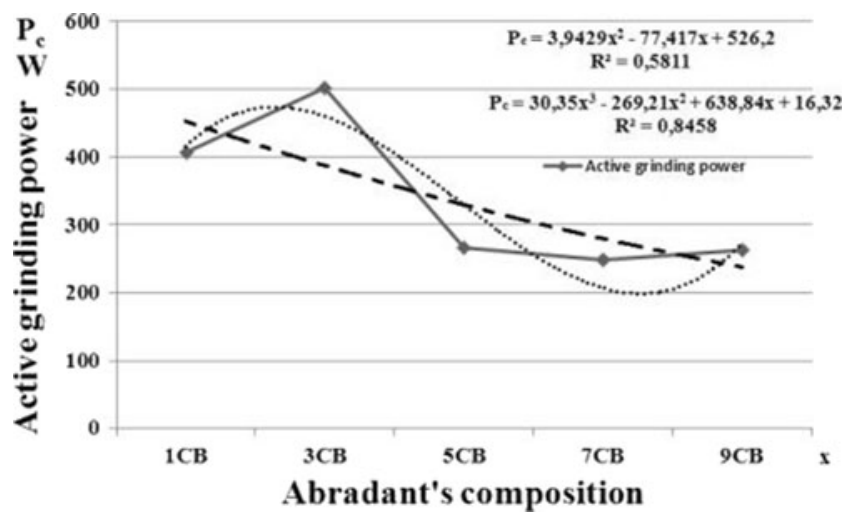

Fig. 16 The influence of microcrystalline sintered corundum abradant composition on active grinding power

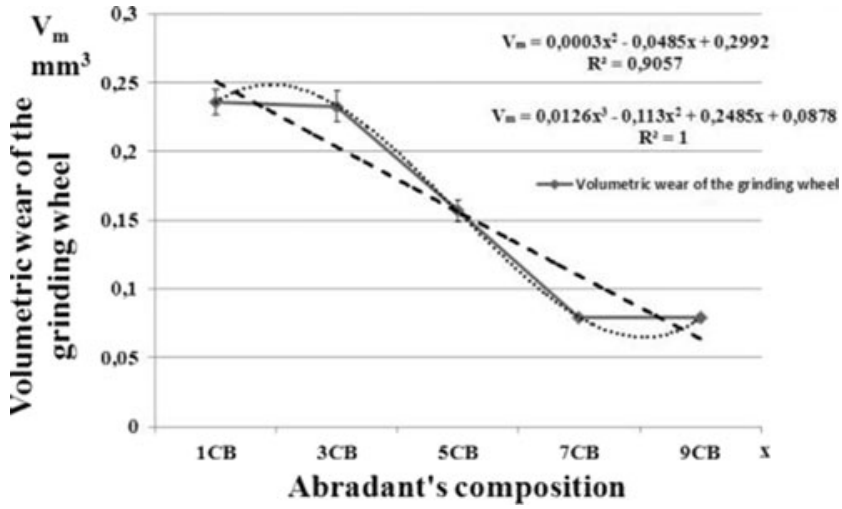

Fig. 17 The influence of microcrystalline sintered corundum abradant composition on the volumetric wear of the grinding wheel

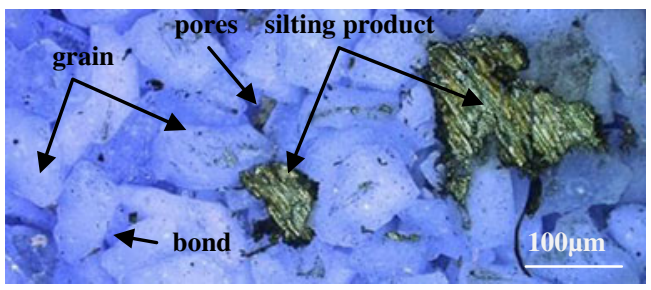

Fig. 18 A view of an active grinding wheel's surface, with the $3 \mathrm{CB}$ abradant composition, upon grinding completion

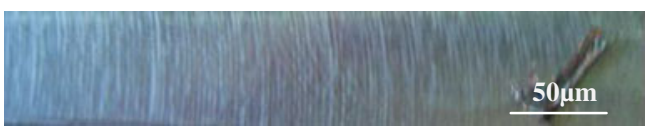

Fig. 19 A view of the machined surface, with a sticking chip removed from the active grinding wheel's surface 


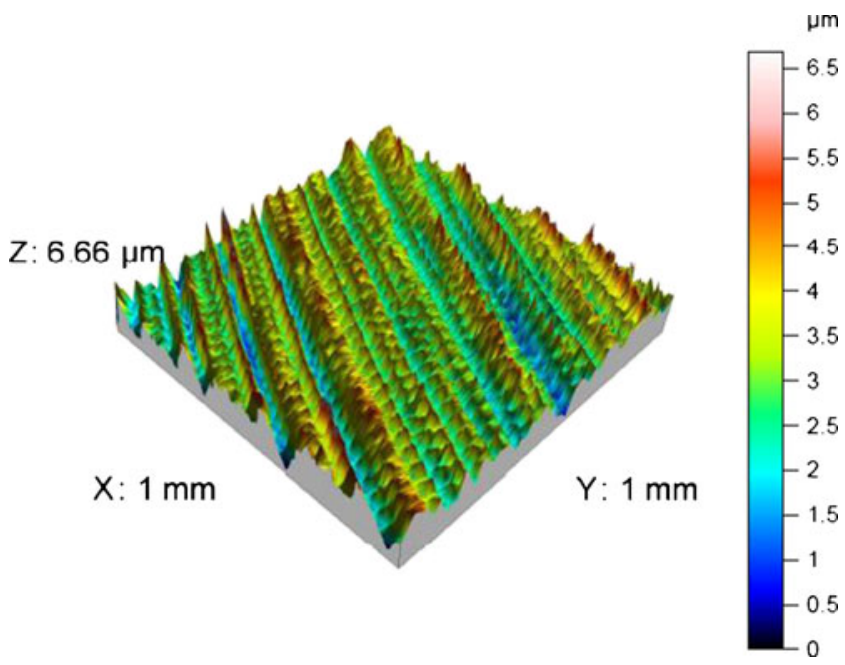

Fig. 20 Topography of the surface machined with a $3 \mathrm{CB}$ grinding wheel

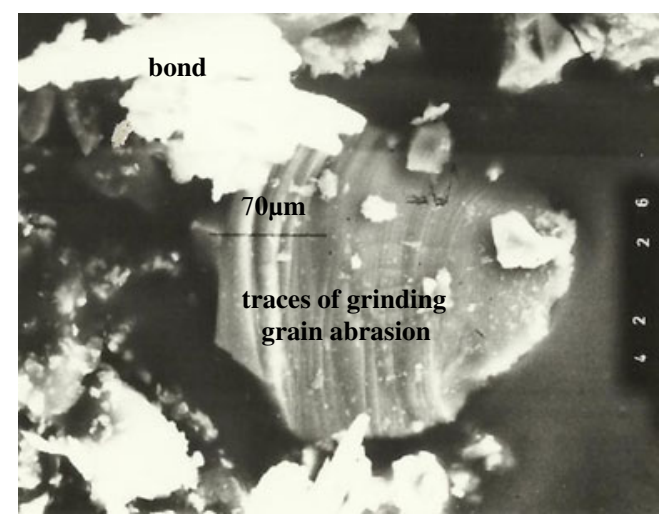

Fig. 21 A scanning image of the dominating form of grinding grain wear when machining with $3 \mathrm{CB}$ grinding wheels

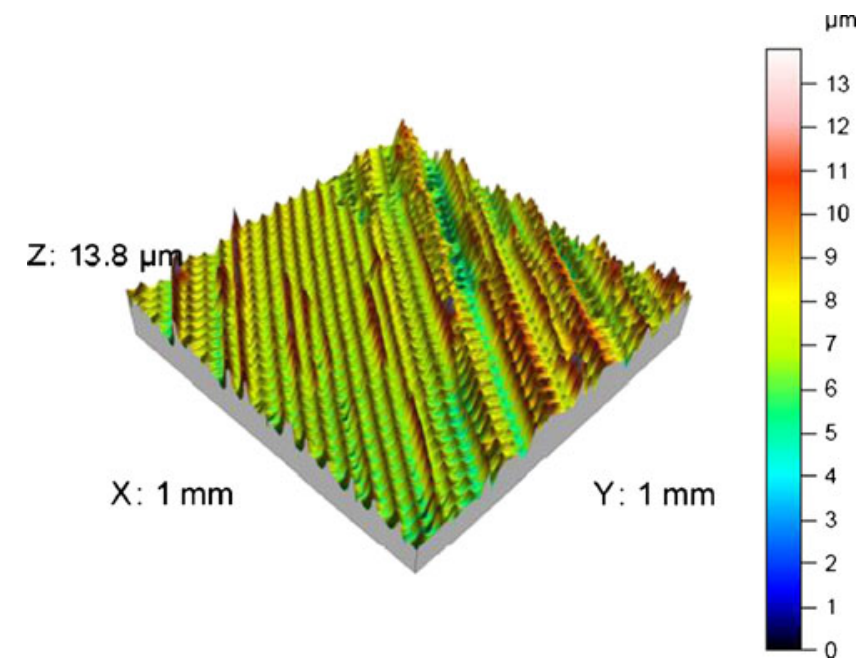

Fig. 22 Topography of the surface machined with a $7 \mathrm{CB}$ grinding wheel

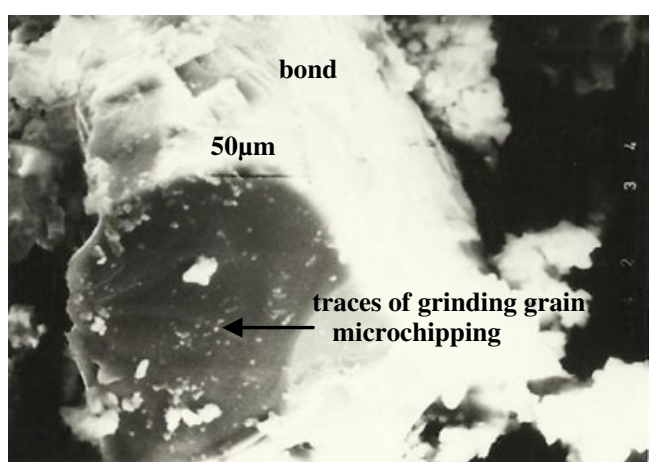

Fig. 23 A scanning image of the dominating form of grinding grain wear when machining with $3 \mathrm{CB}$ grinding wheels

Table 4 Height parameter values of the coarseness of the surfaces machined with $3 \mathrm{CB}$ grinding wheels

\begin{tabular}{llll}
\multicolumn{5}{l}{ ISO 25178} \\
\hline \multicolumn{2}{l}{ Height parameters } \\
\hline $\mathrm{Sq}$ & $0.711 \mu \mathrm{m}$ & $\mathrm{Sv}$ & $2.65 \mu \mathrm{m}$ \\
$\mathrm{Ssk}$ & -0.262 & $\mathrm{Sz}$ & $5.52 \mu \mathrm{m}$ \\
$\mathrm{Sku}$ & 3.62 & $\mathrm{Sa}$ & $0.546 \mu \mathrm{m}$ \\
$\mathrm{Sp}$ & $2.87 \mu \mathrm{m}$ & & \\
\hline
\end{tabular}

Table 5 Height parameter values of the coarseness of the surfaces machined with 7CB grinding wheels

\section{ISO 25178}

Height parameters

\begin{tabular}{llll}
\hline Sq & $1.19 \mu \mathrm{m}$ & $\mathrm{Sv}$ & $6.05 \mu \mathrm{m}$ \\
$\mathrm{Ssk}$ & 0.0363 & $\mathrm{Sz}$ & $11.2 \mu \mathrm{m}$ \\
$\mathrm{Sku}$ & 4.67 & $\mathrm{Sa}$ & $0.878 \mu \mathrm{m}$ \\
$\mathrm{Sp}$ & $5.2 \mu \mathrm{m}$ & & \\
\hline
\end{tabular}




\section{Conclusions}

Based on the statistically and substantively analyzed test results, it was found that, in the conditions of front finishing grinding of flat surfaces of the objects made of austenitic corrosion-resistant steel, using microcrystalline sintered corundum grinding wheels, the following regularities were found:

- The composition of the abradants of the grinding wheels used in tests indicated their significant influence (at the significance coefficient of $\alpha=0.05$ ) on the maximum temperature in the grinding zone, thrust power component, grinding feed power, active grinding power, and volumetric grinding wheel wear.

- Together with the increase of the percentage microcrystalline sintered corundum content in the abradant, the values of the indicated physical parameters displayed a decreasing trend that could be determined by trend functions, in the form of second-degree polynomials, without interaction. That contradicted a popular industrial rule under which the respective changes have the nature of linear changes.

- The test results well-approximated the following test object functions:

- $Q_{\max }=48.89(\mathrm{XX})^{3}-435.74(\mathrm{XX})^{2}+1,074.50(\mathrm{XX})-$ 29.90

- $F_{\mathrm{p}}=2.36(\mathrm{XX})^{3}-20.67(\mathrm{XX})^{2}+46.95(\mathrm{XX})+0.23$

$-\quad F_{\mathrm{f}}=1.10(\mathrm{XX})^{3}-9.59(\mathrm{XX})^{2}+21.91(\mathrm{XX})-5.60$

- $P_{\mathrm{c}}=30.35(\mathrm{XX})^{3}-269.21(\mathrm{XX})^{2}+638.84(\mathrm{XX})+16.32$

- $V_{\mathrm{m}}=0.013(\mathrm{XX})^{3}-0.113(\mathrm{XX})^{2}+0.249(\mathrm{XX})+0.088$

Those functions indicated the existence of local extremes in the changes of the selected physical values, depending on the abradant composition changes.

- Synergic influence of the mixed $3 \mathrm{CB}$ abradant on the machined surface caused the occurrence of the wear phenomenon on the active grinding wheel's surface, in the form of gluing (silting), in the assumed machining conditions, which resulted from the specific properties of the ground material (in this case of low thermal conductivity of austenite, its resistance to microchip corrosion, and the adhesion capability).

- In the assumed and similar grinding conditions, it is recommended to apply the grinding wheels with the 7CB-9CB abradant content.
Open Access This article is distributed under the terms of the Creative Commons Attribution License which permits any use, distribution, and reproduction in any medium, provided the original author(s) and the source are credited.

\section{References}

1. Woźniak (1992) Materiały Ścierne - wytwarzanie i własności. Wydawnictwo Naukowo-Techniczne, pp 97-110. Warszawa

2. Marinescu ID, Hitchiner M, Uhlmann E, Rowe WB, Inasaki I (2007) Handbook of machining with grinding wheels.CRC. Boca Raton

3. Klocke F (2009) Manufacturing processes 2: Grinding, honing, lapping. Springer-Verlag, Berlin

4. Niżankowski CZ (1996) Właściwości skrawne ściernic z korundu spiekanego. Wydawnictwo Politechniki Krakowskiej, Monografia 205, Kraków, pp 102-105

5. Heuer W (1990) Gesinteres Aluminiumoxid - ein neuer Schleistoff zum Innenrundschleifen. Wirtschaftliche Alternative. Industrie Anzeiger 112(69):44-46

6. Mayer J, Engelhorn R, Bot R, Weirich TH, Herwartz C, Klocke F (2006) Wear characteristics of second-phased-reinforced sol-gel corundum abrasives. Acta Materialia 54(13):3605-3615

7. Zi-Cheng L, Zhi-Hong L, Ai-Ju Z, Yu-Mei Z (2009) Synthesis and two-step sintering behavior of sol-gel derived nanocrystalline corundum abrasives. J Eur Ceram Soc 29:1337-1345

8. Nadolny K (2012) Wytwarzanie, właściwości zastosowanie ziaren ściernych z mikro- i submikrokrystalicznego korundu spiekanego. Mechanik 10/2012 Wydawnictwo Sigma, pp 850-857

9. Niżankowski CZ (2012) Wpływ składu ścierniwa na zdolność ścierną ściernic z submikrokrystalicznego korundu spiekanego. Monografia nt. Postępy w obróbce ściernej, Oficyna Wydawnicza Politechniki Wrocławskiej. Wrocław

10. Brunner G (1998) Schleifen mit mikrokristallinem Aluminiumoxid. Dr.- Ing. Dissertation, Univ, Hannover

11. Stark C (1997) Potentials of abrasive tools with microcrystalline sintered aluminium oxide. VDI-Z Integrierte Production, Issue II/ 97 Springer-VDI-Verlag GmbH \& Co, Düsseldorf

12. Jackson MJ, Davim JP (2010) Machining with abrasives. Springer, New York

13. Lowin R (1980) Schleiftemperaturen und ihre Auswirkungen im Werkstück. Miss. RWTH, Aachen

14. Ueda T, Hosokawa A, Yamamoto A (1985) Studies on temperature of abrasive grains in grinding - application of infrared radiation pyrometer. J Eng For Industry Trans of ASME 107:127-133

15. Sherman EA, Kortel AA, Zhukovskaya AE, Nechaev YR, Azbel' YI, Shubina AE (1980) A separator for deironing sintered corundum. Refract Ind Ceram Springer-Verlag 21(910):522-524

16. Niżankowski $\mathrm{Cz}$, Sęk K (2012) Badania porównawcze pól temperatury $\mathrm{w}$ procesie czołowego szlifowania płaszczyzn ściernicami z elektrokorundu szlachetnego oraz mikrokrystalicznego korundu spiekanego. The World of Machine Tools 7-9/2012, pp 18 20 